\begin{tabular}{|c|c|c|c|c|c|c|}
\hline \multirow{4}{*}{ Impact Factor: } & ISRA (India) & $=3.117$ & SIS (USA) & $=0.912$ & ICV (Poland) & $=6.630$ \\
\hline & ISI (Dubai, UAE & $=0.829$ & РИНЦ (Russia) & $=0.156$ & PIF (India) & $=1.940$ \\
\hline & GIF (Australia) & $=0.564$ & ESJI (KZ) & $=8.716$ & IBI (India) & $=4.260$ \\
\hline & JIF & $=1.500$ & SJIF (Morocco) & $=5.667$ & OAJI (USA) & $=0.350$ \\
\hline
\end{tabular}

\section{SOI: 1.1/TAS DOI: 10.15863/TAS International Scientific Journal Theoretical \& Applied Science}

p-ISSN: 2308-4944 (print) e-ISSN: 2409-0085 (online)

Year: 2019 Issue: $06 \quad$ Volume: 74

Published: $14.06 .2019 \quad$ http://T-Science.org

SECTION 31. Economic research, finance, innovation, risk management.
QR - Issue

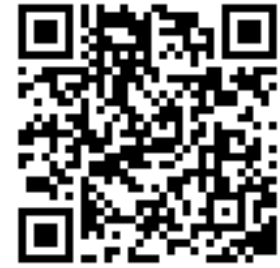

QR - Article

\title{
ISSUES OF IMPROVING URBAN ENVIRONMENTAL MANAGEMENT EFFICIENCY AND DEVELOPMENT OF HOUSING AND COMMUNAL ECONOMY IN THE STRENGTHENING URBANIZATION CONDITIONS
}

Abstract: Being an objectively necessary process, urbanization has a significant impact on the urban environment and housing and communal services. These issues are given priority attention in Uzbekistan. Significant success has been achieved both in the provision of housing to the population and in creating a favorable urban environment. The planned urbanization program requires issues rethinking in order to improve urban management itself and housing and utilities development.

Key words: management, urbanization, urban environment, housing and communal services development.

Language: English

Citation: Khairova, D. R. (2019). Issues of improving urban environmental management efficiency and development of housing and communal economy in the strengthening urbanization conditions. ISJ Theoretical \& Applied Science, 06 (74), 170-178.

Soi: http://s-o-i.org/1.1/TAS-06-74-18 Doi: crossef https://dx.doi.org/10.15863/TAS.2019.06.74.18

Actuality of researching the problems.

In the modern world, urbanization is an objective process that reflects the development of productive forces. The increase in the number of cities, and especially their enlargement, the creation of megacities and conglomerations create various socioeconomic problems, associated with the creation and maintenance of an adequate urban infrastructure. Uzbekistan also has these problems because of its regional specificity that has developed.

The actuality of researching the problems of managing urban infrastructure in the conditions of Uzbekistan is, first of all, connected with high rates of demographic growth and urbanization, which have a large-scale impact on the development of cities and towns of the Republic. In modern conditions, housing and communal activities are the organizing principle in the life of the city. It is the basis keeping and developing the city as a human habitat. The generally beneficial nature of public service systems is confirmed by their status of permanent installations, which are ready to meet the needs of the population and the city in the relevant services.

In modern conditions, housing and communal services is a complex of sub-sectors, designed to ensure the conditions of normal life of the population and the urban structures functioning. Housing and communal services form the living environment of humans in significant way. It ensures the comfort of the city, the district, the neighborhood and the dwelling. On the one hand, this industry is under the influence of developing market relations, and on the other, it is an important element of the system of social protection of the population.

It is obvious that housing and communal services is a service industry and the most important part of the territorial infrastructure that determines the conditions of human life, the comfort of dwelling, engineering improvement, quality and reliability of transport, communications, household and other services as they influence health, quality of life and social climate of the urban environment.

As a rule, the housing and utilities sector has the following sub-sectors:

- housing and maintenance services;

- water supply and sanitation;

- municipal energy (electricity, heat, gas);

- urban public transport;

- information services (cable networks, satellite television, fiber optic systems and electronic communication channels, computer software and communication systems); 


\begin{tabular}{|c|c|c|c|c|c|c|}
\hline \multirow{4}{*}{ Impact Factor: } & ISRA (India) & $=3.117$ & SIS (USA) & $=0.912$ & ICV (Poland) & $=6.630$ \\
\hline & ISI (Dubai, UAI & $=0.829$ & РИНЦ (Russia & $=0.156$ & PIF (India) & $=1.940$ \\
\hline & GIF (Australia) & $=0.564$ & ESJI (KZ) & $=8.716$ & IBI (India) & $=4.260$ \\
\hline & JIF & $=1.500$ & SJIF (Morocco & $=5.667$ & OAJI (USA) & $=0.350$ \\
\hline
\end{tabular}

- external urban improvement, including road facilities and road construction;

- sanitary cleaning of territories (street cleaning, house cleaning with utilization of household and food waste);

- green farming services (urban greening, floriculture);

- hotel industry;

- consumer services (baths, laundries, ritual services);

- street lighting.

Each of these sub-sectors is currently undergoing profound innovative technological-technological transformations. The purposes of these transformations are:

- expanding the sub-industry functions and providing additional options and services on this basis;

- improving the quality of standard services;

- ensuring a higher level of resource conservation;

- reducing material costs for the production of used units and devices;

- providing the environmental protection.

It should be noted that the environmental protection has a dynamically increasing priority. It is obviously due to the increase in the city sizes, motorization, consumption of goods and, in general, anthropogenic impact on the environment.

The process of innovative renewal in this area is continuous and accelerating when the emergence of the subsequent innovative technology " $\mathrm{B}$ " comes before the moment of physical wear of the equipment of the previous technology " $A$ ". The presence of such a phenomenon becomes more normal and, of course, it requires the research, as there are large reserves of resource savings.

One of the important courses of socio-economic development in Uzbekistan has been the intensification of the urbanization process. Thus, in the Message of the President of the Republic of Uzbekistan to the Oliy Majlis dated December 28, 2018 , it is noted that "Today the level of urbanization in the country is 35.5 percent, and if you do not take any actions today, then there is a possibility of a decrease in this indicator." That is why the country plans to "develop a State Program in order to increase the level of urbanization in the country up to 60 percent by 2030". Here, of course, it is necessary to take into account any development related to renovation [5], as it allows merging two processes into one: demolishing obsolete housing and building modern comfortable residential buildings.

The development of urbanization is an objective process that positively affects macroeconomic indicators. Thus, currently in Uzbekistan over 70 percent of GDP is created in cities at a specified level of urbanization. Even if we consider that there is a certain disproportion in the prices of industrial and agricultural products, the contribution of citizens to the creation of GDP per capita is several times greater than the contribution of villagers.

Certainly, urbanization development will affect significantly and qualitatively the considerable complication of housing and utilities management, as the growth in management complexity depends on the increase in city sizes, and it is not linear. And, in certain conditions some new factors appear. Considering these phenomena from a theoretical perspective, there are grounds to confirm the opinions of a number of researchers that at the present stage of development of the productive forces, the society itself shows the singularity of development increasingly.

In the conditions of urbanization growth, nontraditional, innovative solutions are needed, as they will ensure a qualitatively new development in such sectors as healthcare, transport, energy and infrastructure. One such solution, for example, is the concept of a "smart city", aiming to ensure the modern quality of life, comfort and stability of the urban population using innovative technologies that provide economical and environmentally friendly use of urban living systems. It is discussed below.

One of the factors shaping the life support of the population is the development of the housing and public utilities sector of the republic, which is the most important part of the territorial infrastructure. It can be stated that the effectiveness of public services forms not only an adequate quality of life for the population, reflecting the degree of society civilization, culture, its welfare and lifestyle, but also serves as one of the most important prerequisites for the development of economic potential, as well as creates the condition for attracting investment.

It should be noted that the sectoral feature of public services is the technologically determined by monopolistic position of enterprises and the close relationship between enterprises in various fields of activity. Another feature is the strictly local production process and the consumption of utilities, their non-interchangeability, the impossibility of delivering services from the outside sources or receiving them somewhere outside the city or the region.

The main feature of housing and communal services, which must necessarily be taken into account when developing measures to increase efficiency, is a pronounced social focus of activities: provision of vital services to all members of society without exception. In turn, this predetermines the primary role of local government bodies and authorities in ensuring the standard functioning and development of the industry with the methodological, legal, scientific, and technical support of republican government bodies. In this case, special attention is paid to the development of engineering infrastructure - this issue is classified 


\begin{tabular}{|c|c|c|c|c|c|c|}
\hline \multirow{4}{*}{ Impact Factor: } & ISRA (India) & $=3.117$ & SIS (USA) & $=0.912$ & ICV (Poland) & $=6.630$ \\
\hline & ISI (Dubai, UAI & $=0.829$ & РИНЦ (Russia & $=0.156$ & PIF (India) & $=1.940$ \\
\hline & GIF (Australia) & $=0.564$ & ESJI (KZ) & $=8.716$ & IBI (India) & $=4.260$ \\
\hline & JIF & $=1.500$ & SJIF (Morocco & $=5.667$ & OAJI (USA) & $=0.350$ \\
\hline
\end{tabular}

as a priority. It should be noted here that the state of engineering communications in the post-Soviet territory, almost everywhere, leaves much to be desired. This negatively affects not only the quality of life, but also all sectors of the economy.

That is why the housing and communal services development policy is based on the priority provision of settlements with roads, water, gas, communications, and electricity in order to create favorable conditions both for living and locating manufacturing enterprises and attracting investments in their development.

It should also be noted that, in accordance with the decree of the President of the Republic of Uzbekistan "On measures for the further implementation and development of modern information and communication technologies" dated March 21, 2012, the Center for the Development and Implementation of Computer and Information Technologies "UZINFOCOM" was given the task to create unified Internet portal housing services. The main purpose of the portal is to create a common communication infrastructure in the housing and utilities sector, which will simplify the exchange of information between the population, regulatory agencies and the Municipal ATP, makhallas (city blocks), as well as public utilities. It will allow establishing feedback and establishing transparent control over the targeted use of public funds, which, in turn, should contribute to improving the quality of utilities provided.

Currently, the portal operates in test mode and is available at e-kommunal.uz, there a single database of public utilities and social services is being formed.

Creation of the portal is the initial stage of transition to digital format and has a number of obvious and encouraging advantages, which are as follows:

- the part of the population that is experiencing difficulties due to lack of time or for some other reasons, especially those with physical disabilities, who are not able to visit the Center for the provision of public services, can use the services of the "Electronic Portal" and solve all issues on-line;

- the work of the state and municipal servants themselves is greatly simplified;

- the use of such a management system also leads to the reduction of criminality (reducing the possibility of bribery).

It is obvious that the provision of housing to the population is not only a priority social problem, but also one of the mandatory attributes providing and posing standard functioning of a person. It means that it carries an important social burden, consisting of providing favorable conditions for the creation and development of the primary cell of society - the family. Developing it, it can be noted that one of the historically established brackets of the national mentality of the Uzbek people is the family, in
Uzbekistan the development of housing construction and housing maintenance in Uzbekistan has always been a problem that requires serious and constant attention from the State itself. The evidence of it, many Decrees of the President of the Republic and Resolutions of the Cabinet of Ministers of the Republic of Uzbekistan. Such close attention to the issue of housing provision is also caused by the current demographic situation and the presence of internal migration.

The Strategy of Action approved by the President of Uzbekistan in five priority areas of the country's development in 2017-2021, developed on the basis of a comprehensive research of topical and affecting all strata of the population and entrepreneurs, analysis of legislation, law enforcement practice and foreign experience, highlights one of the priorities - the development of the social sphere. It states for:

- implementation of targeted programs for the construction of affordable housing, the development and modernization of road transport, engineering, communication and social infrastructure in order to improve living conditions for the population;

- further improvement of the living conditions of the population, especially young families (due to the demographic features of Uzbekistan as a significant proportion of this category of the population), residents of dilapidated houses and other categories of citizens who need better housing conditions by providing mortgage loans on favorable terms and affordable housing in cities and rural areas;

- increasing the level of provision with public utilities, and above all, drastically improving the provision of the population in rural areas with clean drinking water through the construction of new water lines and the consistent introduction of modern, costeffective and efficient technologies;

- ensuring the environmental safety of human habitation, construction and modernization of household waste processing facilities, strengthening their material and technical base, providing the population with modern waste disposal facilities;

- radical improvement of transport services to the population, improvement of passenger traffic safety and reduction of harmful emissions into the atmosphere, renewal of the urban public transport via the acquisition of new comfortable buses, construction and reconstruction of bus terminals and bus stations;

- further construction and reconstruction of road infrastructure, primarily the development of regional highways, major and current repairs of interfarm rural highways, streets of inhabited localities;

- provision improvement of electric power to the population on the basis of building new and modernizing existing power generating capacities, updating low-voltage electrical networks and transformer stations, and implementing measures to 


\begin{tabular}{|c|c|c|c|c|c|c|}
\hline \multirow{4}{*}{ Impact Factor: } & ISRA (India) & $=3.117$ & SIS (USA) & $=0.912$ & ICV (Poland) & $=6.630$ \\
\hline & ISI (Dubai, UAE & $=0.829$ & РИНЦ (Russia & $=0.156$ & PIF (India) & $=1.940$ \\
\hline & GIF (Australia) & $=0.564$ & ESJI (KZ) & $=8.716$ & IBI (India) & $=4.260$ \\
\hline & JIF & $=1.500$ & SJIF (Morocce & $=5.667$ & OAJI (USA) & $=0.350$ \\
\hline
\end{tabular}

improve the provision of other fuel and energy resources to the population and expanding the use of renewable energy sources.

One of the important issues is the Program for the Development of the Service sector in 2016-2020 in the Republic (Table 1).

In order to improve the quality of services provided for comfortable living of citizens, the Cabinet of Ministers of the Republic of Uzbekistan decides considering the priorities and objectives in the development of the service sector in the Republic of Uzbekistan in 2016-2020:

- an increase in the gross domestic product due to the development of the service sector, bringing its share in the economy of the republic to 60 percent;

- the growth of services in rural areas by 2020 by 1.8 times;

- the creation of conditions for the fast development of the service sector, structural changes due to the development of engineering and communication, road and transport infrastructure, implementation of modern information and communication technologies in the sectors;

- the expansion of a variety of innovative services and new means of communication;

- ensuring the technical possibilities of accessibility of the population to the telecommunications network, providing quality services on their basis, full transition to digital telephone and television systems, bringing the share of communication services and informatization in the republic's economy to 2.5 percent by 2020 ;

- the development of financial services with the introduction of the latest electronic, payment technologies;

- further development of high-tech services in the health sector.

Table 1. TARGET PARAMETERS

Development of the service sector in the Republic of Uzbekistan in 2016 - 2020

\begin{tabular}{|l|l|l|}
\hline$№$ & Services list & $\mathbf{2 0 2 0}$ by \% to 2015 \\
\hline & The Republic of Uzbekistan & $\mathbf{1 , 8}$ times \\
\hline & Including: & \\
\hline 1. & communication and information services & 2,9 times \\
\hline 2. & financial services & 1,8 times \\
\hline 3. & transportation services & 1,5 times \\
\hline 3.1 & including motor transport services & 1,5 times \\
\hline 4. & accommodation and food services & 1,8 times \\
\hline 5. & trade services & 1,6 times \\
\hline 6. & real estate related services & 1,5 times \\
\hline 7. & educational services & 1,5 times \\
\hline 8. & health services & 1,9 times \\
\hline 9. & rental and rental services & 1,8 times \\
\hline 10. & computers and household goods repair services & 1,6 times \\
\hline 11. & individual services & 1,7 times \\
\hline 12. & services in the field of architecture, engineering research, technical testing and analysis & 1,7 times \\
\hline 13. & other services & 1,8 times \\
\hline
\end{tabular}

At the same time, the share of services in GDP in 2019 should be $59.5 \%$.

To increase the efficiency of housing and public utilities search ways are carried out in all CIS countries. The range of research covers all activities in both urban infrastructure and the management of apartment buildings $[10,11,12]$. Some research works clarify the role of state bodies and business structures in the management of housing and public utilities [10], determine the strategic priorities for the modernization of housing and utilities management [11]. Options for managing households in apartment buildings are being considered [12].

As it is known, high population growth and household structure (HS) significantly influence the housing sector, the demand for housing, thereby causing a high load on the existing engineering infrastructure and land use.

During the years of independent development of our country the housing sector has shown positive results, in particular in 1991, the total area of the housing stock was 258.4 million square meters, and by the end of $2016-2017$, it reached 477.8 million square meters. It means the increase was 1.9 times.

Over the past 28 years, the population of Uzbekistan has grown by more than 1.5 times. Thus, if in 1990 the population of the country was about 20.0 million people, so as for the April 1, 2019 it reached 33.375 million people. Despite a serious demographic burden, Uzbekistan has achieved a steady growth in the provision of housing to the population - per person 


\begin{tabular}{|c|c|c|c|c|c|c|}
\hline \multirow{4}{*}{ Impact Factor: } & ISRA (India) & $=3.117$ & SIS (USA) & $=0.912$ & ICV (Poland) & $=6.630$ \\
\hline & ISI (Dubai, UAE & $=0.829$ & РИНЦ (Russia & $=0.156$ & PIF (India) & $=1.940$ \\
\hline & GIF (Australia) & $=0.564$ & ESJI (KZ) & $=8.716$ & IBI (India) & $=4.260$ \\
\hline & JIF & $=1.500$ & SJIF (Morocce & $=5.667$ & OAJI (USA) & $=0.350$ \\
\hline
\end{tabular}

from 12.4 to 15.5 square meters. (fig. 1) [9,10]. So,the

growth was 1.2 times.

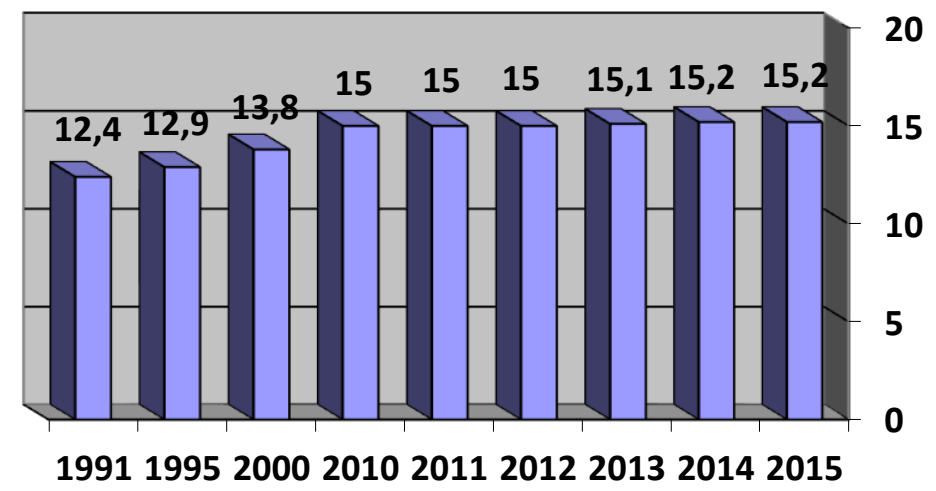

20

15

$\square$ sq.m of living

space per 1

inhabitant

Figure 1. Provision of housing in 1991-2015

In 2016, the Institute of Social Research conducted a sociological survey of 1008 rural households in three regions of the Republic of Uzbekistan, they are Khorezm, Fergana, and Kashkadarya regions with a direct study of living conditions. The selected regions reflect typical climatic (desert, flat, and mountainous areas), socioeconomic, and demographic characteristics of many regions of the republic and present the necessary information base to obtain data.
As the analysis showed a number of systemic problems, despite the positive changes in the improvement of living conditions (Diagram 1). The main problem, namely $60.2 \%$ of households in rural areas need additional housing, $15.4 \%$ need major repairs, $12.8 \%$ of respondents indicated that there is not enough living space, and $7.6 \%$ said that the total area is not enough plot.

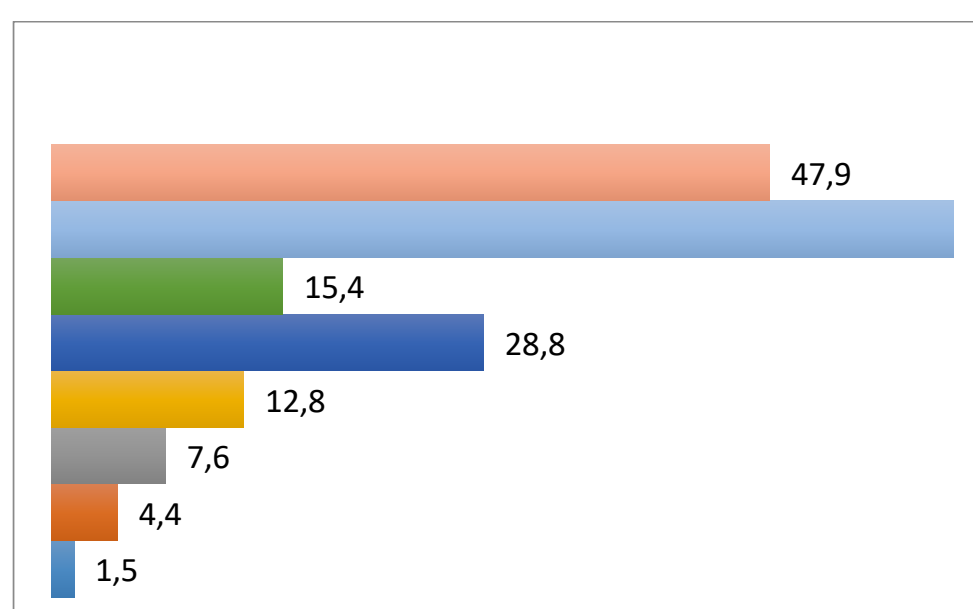

we are satisfied

60,2

need additional housing

need a major overhoul

need cosmetic repairs

not enough living space

not enough total area

other

hard to answer

Diagram 1. Most frequently reported housing problems \%

The most frequent highlighted problems are the need in additional housing territory and lack of housing space, primarily from the HS consisting of 5 or more members, as well as a high concentration of families living in the same HS (2-3 or even 4 families), i.e. high demographic load. In general, the main housing problem in the countryside is the need based on the constant growth in the number of household members.
Thus, Uzbekistan is developing a new program for the construction of affordable housing in rural areas for 2017-2021 (Pic. 2)

Only in 2017, 2 trillion 121 billion soums were allocated to finance the program. It is planned to attract credit resources of commercial banks in the amount of more than 2 trillion soums (about 675 million dollars).

The measures taken contribute to provide families with modern, high-quality, comfortable 


\begin{tabular}{|c|c|c|c|c|c|c|}
\hline \multirow{4}{*}{ Impact Factor: } & ISRA (India) & $=3.117$ & SIS (USA) & $=0.912$ & ICV (Poland) & $=6.630$ \\
\hline & ISI (Dubai, UAE & $=0.829$ & РИНЦ (Russia & $=0.156$ & PIF (India) & $=1.940$ \\
\hline & GIF (Australia) & $=0.564$ & ESJI (KZ) & $=8.716$ & IBI (India) & $=4.260$ \\
\hline & JIF & $=1.500$ & SJIF (Morocce & $=5.667$ & OAJI (USA) & $=0.350$ \\
\hline
\end{tabular}

housing and form a new engineering and communication, social and market infrastructure in the countryside. It allows raising the image of the village to a qualitatively new level and, on this basis, raising the standard of living and changing the outlook of the rural population.

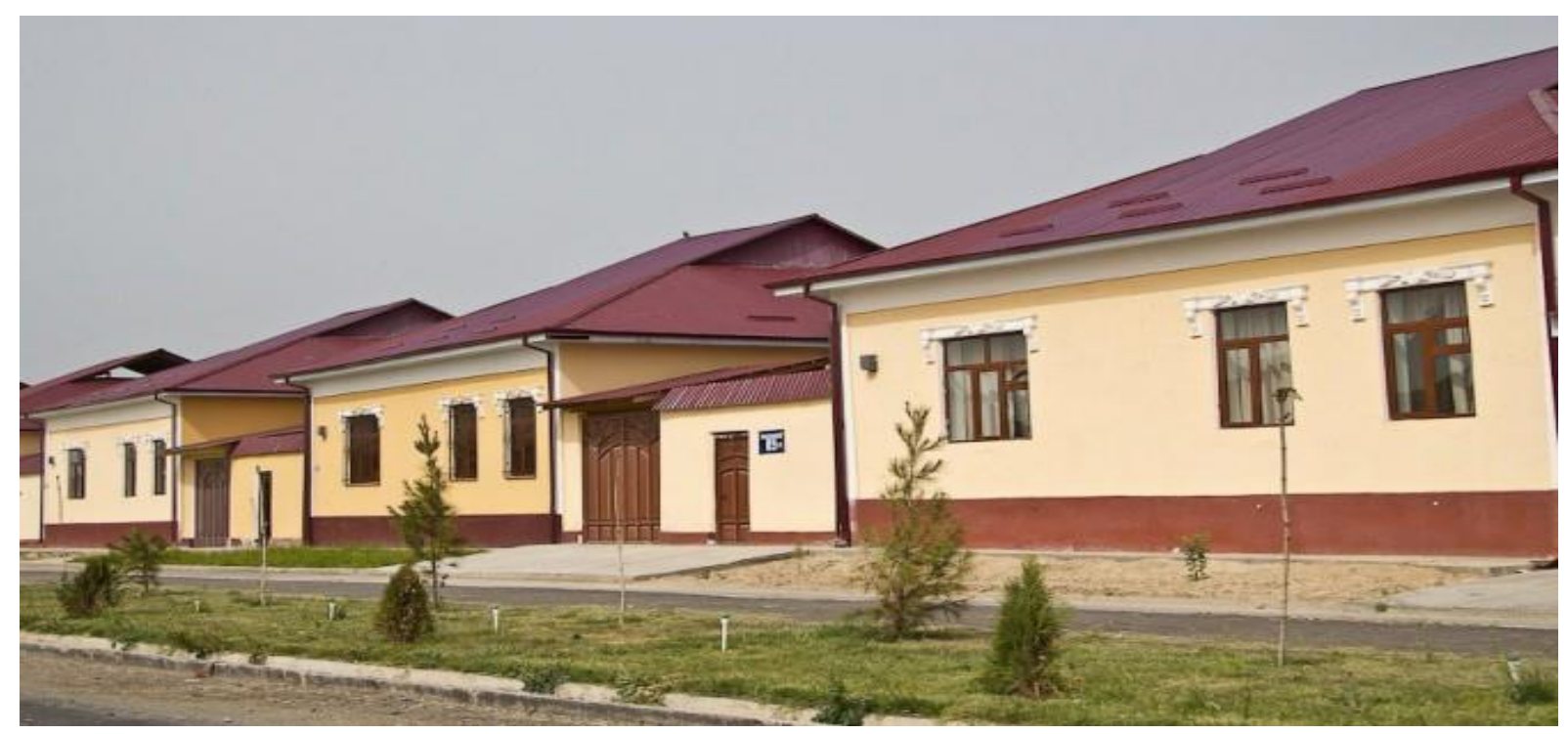

Picture 2. Typical rural housing project

As a result of the analysis of the demographic situation in the country, the state of the housing stock and its growth rates, it can be concluded that construction volumes in Uzbekistan are not sufficient, and to achieve the level of developed countries, it is necessary to take extraordinary measures.

As international experience shows the state of urban infrastructure occupies an important place in the strategy of modernizing any state and raising the industrial and innovative level of the national economy. It, in turn, necessitates the creation of an effective system of urban infrastructure management, based on a new mechanism of territorial management and a strategic approach to urban development. Such mechanism should be focused on improving the quality of life of the population, on strengthening the economic independence of cities, on improving the efficiency and complexity of their development, on creating favorable conditions for the competitive functioning of market structures and attracting investment resources.

Accessibility of services is a characteristic feature of housing and public utilities. The vital and irreplaceable nature of the consumption of utilities requires to be equally accessible to all who need them, and be always available when they are needed, regardless of the solvency of consumers. The more reliable and efficient the functioning of the engineering systems of the city are more convenient, comfortable and favorable, the urban environment is perceived for the population and the functioning of various organizations. Full or general availability of services is an indicator of comfort and quality of modern housing.
The main objectives of the ongoing modernization of housing and communal services are:

- improving the quality of housing and communal services, provided to the public;

- attracting private investment in the industry;

- reducing the costs of housing production utilities;

- improving the sustainability of the industry.

World practice shows that in order to meet the challenges of developing urban infrastructure successfully, it is necessary to create an effective system for its management, based on a modern mechanism of territorial management and a strategic approach to the city development.

Such mechanism should be focused on improving the quality of life of the population, strengthening the economic independence and importance of cities, increasing the efficiency and comprehensiveness of the development of the territory, creating favorable conditions for the competitive functioning of market structures and attracting investment resources. The key element in the improvement of infrastructure management is a significant increase in the role and responsibility of city and district authorities (hokimiyats).

The goal of improving the organizational structures for managing urban infrastructure in Uzbekistan is to optimize costs, ensure a high level of manageability, improve the quality of services, and the responsibility of departments for the results of their activities. At the same time, the urban infrastructure management scheme, as well as the mechanisms for financing life-support facilities, 


\begin{tabular}{|c|c|c|c|c|c|c|}
\hline \multirow{4}{*}{ Impact Factor: } & ISRA (India) & $=3.117$ & SIS (USA) & $=0.912$ & ICV (Poland) & $=6.630$ \\
\hline & ISI (Dubai, UAE & $=0.829$ & РИНЦ (Russia & $=0.156$ & PIF (India) & $=1.940$ \\
\hline & GIF (Australia) & $=0.564$ & ESJI (KZ) & $=8.716$ & IBI (India) & $=4.260$ \\
\hline & JIF & $=1.500$ & SJIF (Morocce & $=5.667$ & OAJI (USA) & $=0.350$ \\
\hline
\end{tabular}

should correspond to the scale of demographic, migration and urbanization processes in the republic.

1. In order to ensure a faster pace of development of infrastructure and favorable conditions in cities, it seems expedient to establish a
City Infrastructure Management Department (hereinafter referred to as the Department).

2. The department should have the status of a single owner of the infrastructure of the city and the state customer (Figure 2).

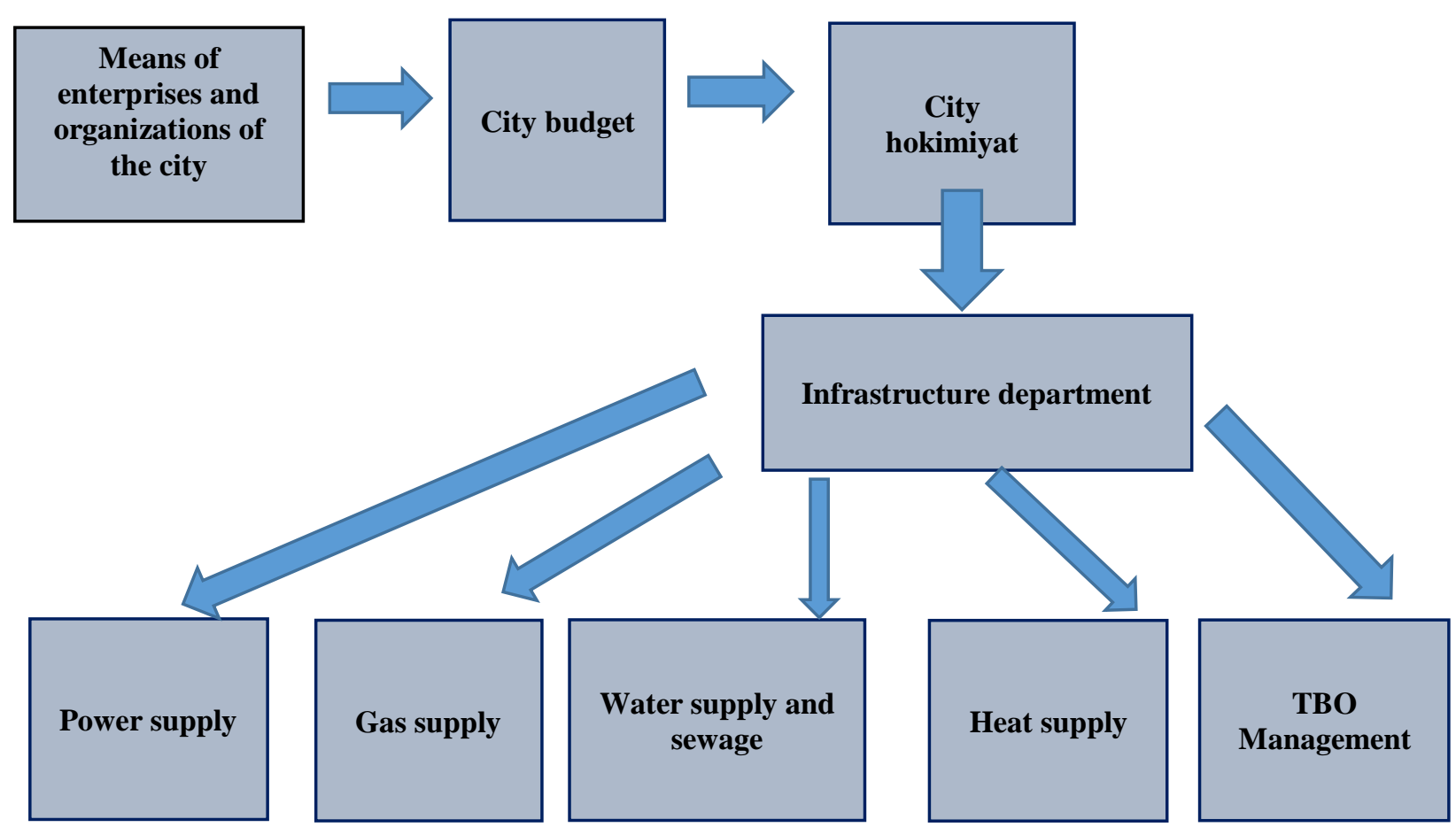

Figure 3 - Schematic diagram of the organization of the municipal order and the financing of urban infrastructure.

3. The property of the Department is formed at the expense of the property assigned by the founder. It implies the transfer of all water supply, sewage, heat supply, gas supply, and power supply facilities located in the city (district) in the manner prescribed by law to the ownership of the hokimiyat. The transfer process of gas supply and power supply facilities and networks located in cities to the balance of the city hokimiyat will have a multiplicative effect on management efficiency. It enable JSC "Uzbekenergo" and JC "Uztransgaz" to be relieved of inappropriate functions.

All day-to-day work, including ensuring payment discipline, maintaining urban gas / electricity systems, will be assigned to the Department, which will represent the interests of the city to deal with JSC "Uzbekenergo" and JC "Uztransgaz". In this case, Uzbekenergo and Uztransgaz can concentrate their efforts on strategic issues of increasing the generating and transporting capacities, introducing energysaving technologies and others.

4. The creation of the Department will ensure:

- rational use of budgetary funds allocated for the maintenance, repair and development of urban infrastructure;
- a clear separation of the functions of the customer and the contractor in this area;

- elimination of duplication of control and management, improvement of the efficiency of the public sector;

- strict accounting for material and cash expenses;

- balanced development of infrastructure sectors;

- attraction to this area of high technology;

- the stability of the staffing industry;

- organization of contractual conditions in the field of public services, protection of consumer interests;

- attraction of small business and private entrepreneurship infrastructure projects;

- guidance of payment discipline, reduction of receivables and payables;

- the use of progressive forms, mechanisms and tariff and non-tariff regulation tools;

- increasing the responsibility of market participants for the provision of quality services.

5. The provision of all types of services should be carried out on the basis of contracts between the 


\begin{tabular}{|c|c|c|c|c|c|c|}
\hline \multirow{4}{*}{ Impact Factor: } & ISRA (India) & $=3.117$ & SIS (USA) & $=0.912$ & ICV (Poland) & $=6.630$ \\
\hline & ISI (Dubai, UAI & $=0.829$ & РИНЦ (Russia & $=0.156$ & PIF (India) & $=1.940$ \\
\hline & GIF (Australia) & $=0.564$ & ESJI (KZ) & $=8.716$ & IBI (India) & $=4.260$ \\
\hline & JIF & $=1.500$ & SJIF (Morocco & $=5.667$ & OAJI (USA) & $=0.350$ \\
\hline
\end{tabular}

supplier and the buyer of services. Some infrastructure facilities may be transferred to private companies on contractual terms, for example, management of municipal solid waste (in this case, tariff regulation should remain with the Department). In accordance with the established procedure, the Department selects a non-profit management company with the inclusion of its representatives in its board of managers. The department applies various schemes for attracting citizens' self-government organizations to the management sector.

Thus, the experience of developed countries indicates the direct dependence of the GDP growth rate on the level of urban development. And the level of urban development, in turn, directly depends on the capacity, sustainable operation of infrastructure facilities and the quality of management of urban infrastructure. In this regard, in most developed countries, urban infrastructure is owned and operated directly by city (municipal) authorities. It is obvious that the state resources allocated for the development and support of infrastructure are not highly profitable. Nevertheless, it is the infrastructure that has a multiplicative effect on attracting foreign direct investment (FDI), the development of cities as centers of industrial-innovative development, and an increase in the quality of life of the urban population.

In recent years, huge state investments have been made for the construction, reconstruction and modernization of the integrated system of the urban infrastructure of the Republic of Uzbekistan. All spheres of urban infrastructure and public utilities, the state and local budget are being reformed step by step.

At the same time, high rates of demographic growth, concentration in the cities of industrial production, development and other factors put forward entirely new and increased demands on the urban infrastructure. On the one hand, new challenges in this area are connected with the acceleration of urbanization, the implementation of modernization programs, technical and technological renewal of key industries, the creation of the modern appearance of cities that are not inferior to international standards.
On the other hand, the challenges are related to the exacerbation of problems of heat supply, water supply, sewage, energy supply and municipal waste management, a drop in capacity, an increase in nonproduction costs, depletion of engineering communications resources, a decrease in technical and technological potential of a number of infrastructure sectors, a sharp increase in receivables and payables.

The key problem of the sector is the inconsistency of the institutional system, methods and mechanisms of managing the urban infrastructure with the modern requirements of fast industrial and innovative development of the country's economy. By further delegating the powers of the central government and local administration, increasing the competence and responsibility of local government bodies, as well as the role of the local budget it would be possible to build a proper system for managing urban infrastructure.

Thus, in the context of urbanization, the issues of increasing efficiency and improving housing management are of particular importance. In Uzbekistan, despite the difficult demographic situation, positive results have been achieved in the growth of housing provision, in the growth of improvement of cities and rural settlements. In general, the problems under consideration are of a priority nature and are under scrutiny from state bodies in Uzbekistan.

The accelerated urbanization program outlined in the country poses new challenges in the housing and utilities sector. Based on the experience of developed countries and taking into account the peculiarities of modern development of urban infrastructure, and in order to ensure faster rates of infrastructure development and favorable conditions in cities, it seems expedient to create a Department of Urban Infrastructure Management at khokimiyats. It will improve the level of manageability and quality of service.

\section{References:}

1. (2017). Edict of the President of the Republic of Uzbekistan "On the strategy of actions for the further development of the Republic of Uzbekistan" No. EP-4947, dated February 7, 2017. Retrieved 2019, from http://nrm.uz/contentf

2. (n.d.). Resolution of the President of the Republic of Uzbekistan "On measures for the further implementation and development of modern information and communication technologies" dated March 21, 2012y No. RP 1730. (Collection of Legislation of the Republic of Uzbekistan, 2012y, No. 13, Article 139, 2013y, No. 44, Resolution Art. 584; 2017, No. 2, Art. 25 National Legislation Database, 01.12.2017y, No. 07/17/3415/0345)

3. (n.d.). Resolution of the Cabinet of Ministers of February 26, 2016y No. 55 "On the Program for 


\begin{tabular}{|c|c|c|c|c|c|c|}
\hline \multirow{4}{*}{ Impact Factor: } & ISRA (India) & $=3.117$ & SIS (USA) & $=0.912$ & ICV (Poland) & $=6.630$ \\
\hline & ISI (Dubai, UAI & $=0.829$ & РИНЦ (Russia & $=0.156$ & PIF (India) & $=1.940$ \\
\hline & GIF (Australia) & $=0.564$ & ESJI (KZ) & $=8.716$ & IBI (India) & $=4.260$ \\
\hline & JIF & $=1.500$ & SJIF (Morocce & $=5.667$ & OAJI (USA) & $=0.350$ \\
\hline
\end{tabular}

the Development of the Service Sector for 20162020y" - Collected Legislation of the Republic of Uzbekistan, 2016y, No. 9, Art. 89, No. 27, Art. 326; 2017y, No. 15, Art. 257, No. 33, Art. 863

4. (2013). Urbanization in Central Asia: challenges, problems and prospects. (Analytical report 2013/03). Tashkent, Center for Economic Research.

5. Krylov, V. A., \& Mokronosov, A. G. (2000). Formation and development of the market of housing and communal services. Ekaterinburg: Ekaterinburg publishing house.

6. (2006). Rules and regulations of the technical operation of the housing stock. MZHKH-M: Stroiizdat.

7. (2000). Housing and utilities. Journal of the head and chief accountant.

8. Kruglikov, A. A. (2006). State policy in the sphere of housing and communal services. Journal of the head and chief accountant of housing and public utilities, №7.

9. Khokhlov, O. B. (2015). Evaluation of the effectiveness of projects and programs for the renovation of the housing stock. Thesis on the competition, academic degree: candidate of economic sciences, TUAC, p.135.

10. Kozhevnikov, S. A. (2015). The interaction of government and business structures in managing the economy of the European north of Russia in the field of housing and public utilities. Thesis on the competition, academic degree: candidate of economic sciences, Vologda, Institute of
Socio-Economic Development of the Territories, RAS, p.161.

11. Melnikov, P. S. (2010). Strategic priorities of modernization of management of the sphere of housing-and-municipal services, abstractdissertation, academic degree: candidate of economic sciences, Shakhty, SEI, HVE, Russian State Social University, p.228.

12. Buryak, A. S., \& Leonova, Z. K. (2016). The problem of choosing a management model in multi-apartment buildings. Internet-journal “SCIENCE" Volume 8, №4. http://naukovedenie.ru/PDF/56EVN416.pdf

13. (2014). Housing of Uzbekistan (brief review). (pp.10-11). Tashkent. www.unece.org

14. (2016). Social development and living standards in Uzbekistan. Statistical compilation of the State Statistics Committee of the Republic of Uzbekistan.

15. (2017). Statistical compilation "Construction in Uzbekistan".

16. (n.d.). Retrieved 2019, from http://rb.ru/story/smart-future/

17. (n.d.). Retrieved 2019, from http://greencapacity.ru/ru/information/smart$\underline{\text { cities }}$

18. (n.d.). Retrieved 2019, from https://www.gazeta.uz

19. (n.d.). Retrieved 2019, from http://www.trend.az/casia/uzbekistan/2676791. html

20. (n.d.). Retrieved 2019, from http://www.UzDaily.uz 